\title{
The Relationship between Parenting Patterns and Fish Consumption in Elementary School-Age Children in West Aceh District
}

\author{
${ }^{1 *}$ Wardah Iskandar, ${ }^{2}$ Sri Wahyuni Muhsin, ${ }^{3}$ Sukma Elida, ${ }^{4}$ Hanif Muchdatul Ayunda \\ ${ }^{1}$ Nutrition Department, Universitas Teuku Umar, Indonesia, wardahiskandar@utu.ac.id \\ ${ }^{2}$ Nutrition Department, Universitas Teuku Umar, Indonesia, sriwahyunimuhsin@utu.ac.id \\ ${ }^{3}$ Nutrition Department, Universitas Teuku Umar, Indonesia, sukmaelida@utu.ac.id \\ ${ }^{4}$ Nutrition Department, Universitas Teuku Umar, Indonesia, hanifmuchdatul@utu.ac.id \\ Coresponding author: Wardah Iskandar, e-mail: wardahiskandar@utu.ac.id
}

\section{ABSTRACT}

Seafood is a nutrient-dense food that is needed by children in their infancy. Sea fish is rich in protein, vitamins and minerals as well as omega 3 fatty acids which are very important for the growth of both body cells and brain cells. Several factors are identified as the cause of low fish consumption in Indonesia, among others, the lack of public understanding of nutrition and the benefits of fish consumption for health and intelligence, socio-economy and culture. So that it affects the parenting style of parents in providing food intake to children. The large protein content in fish is expected to be able to improve the nutritional needs of the Indonesian people and the increase in fish consumption is also expected to have an effect on increasing the intelligence of the Indonesian people. The research aimed to determine the relationship between parenting and fish consumption among school-age children in Aceh Barat District. This study was a cross-sectional study. The sample in this study amounted to 173 elementary school age children in grades IV and V. The data was collected by means of direct interviews which included the patterns of upbringing and fish consumption. Data analysis includes univariate and bivariate analysis with independent sample t-test. From 173 children, it was found that $80.3 \%$ of children consumed fish well, while only $19.7 \%$ of children with poor fish consumption. Maternal parenting affects children's fish consumption with an OR $=12.865(95 \%$ CI 4.933-3.552) so that maternal parenting has a 12.86 times chance of influencing fish consumption in children.
\end{abstract}

How to cite this article: Iskandar, W., Muhsin, S. W., Elida, S., Ayunda, H. M. (2021). The Relationship between Parenting Patterns and Fish Consumption in Elementary School-Age Children in West Aceh District. JNS: Journal of Nutrition Science, 2(1), 31-33

\section{ARTICLE INFORMATION}

\author{
Submitted: $26 / 05 / 2021$ \\ Revised: 27/05/2021 \\ Accepted: 31/05/2021 \\ Publish Online: 31/05/2021
}

Keywords:
Children
Fish Consumption
Parenting

Keywords:

Fish Consumption

Parenting

\section{Introduction}

According to article 131 paragraph 1 of Law No.36 of 2009 concerning Health, efforts to care for the health of infants and children must be aimed at preparing future generations who are healthy, intelligent and of good quality. In paragraph 2 , it is also stated that efforts to maintain children's health are carried out from the time the child is still in the womb, born, after birth, and until the age of 18 (Depkes RI, 2009). One of the fundamentals in child development is parenting, parenting can be defined as all the ways parents treat children. Many experts say parenting is an important and fundamental part of preparing children to become

\begin{tabular}{lr}
\hline $\begin{array}{l}\text { Vol. 2, No. 1, May, } 2021 \\
\text { doi: https://doi.org/10.35308/ jns.v2i2.3626 }\end{array}$ & JNS: Journal of Nutrition Science \\
& P- ISSN : 2723-2867, E-ISSN : 2723-2875
\end{tabular}

good societies. It appears that childcare refers to defined general education. Parenting for children is a process of interaction between parents and children. These interactions include care such as from getting enough food, encouraging success and protecting, as well as socializing (Jas \& Meta, 2004).

Talking about food consumption, both at the individual level and household or community food can be viewed from two aspects, namely the quantity aspect and the quality aspect. The quantity aspect includes the amount of food and nutrients consumed, while the quality aspect includes the pattern (diversity, type) of food consumption and the value of nutritional 
quality. Food consumption patterns are eating behaviors that provide an overview of the kinds and amounts of food that a person consumes every day (Karsin, 2004). Fish is a cheap source of protein for people and fish is the main animal food ingredient in Indonesia. Increased consumption of fish, especially those in nutrient-prone groups, will reduce nutritional problems so that an optimal degree of health can be achieved (Hardiansyah and Rimbawan, 2000).

The nutritional content of fish is not only found in the meat but also in the bones of the fish. Research by Bakhtiar et al. (2019) results that food (baked donuts) with the addition of milkfish bone meal can be a source of fulfillment of micro-nutrients in the body in the form of calcium and phosphorus. This is one reason to eat fish.

\section{Method}

This research is a quantitative type with a crosssectional research design to determine the relationship between parenting and fish consumption in elementary school age children, and the observation and measurement of fish consumption in the research object at the same time.

The sample in this study amounted to 173 elementary school age children from grade IV and V elementary schools in West Aceh District. Parenting patterns are measured by observation and interviews using a questionnaire, determining the level of parenting is categorized into 2, namely good and poor. The measurement for fish consumption is by using the FFQ method by looking at the amount, time and weight of fish consumption. The protein requirement of a person is $1 \mathrm{~g} / \mathrm{BW} /$ day where $1 / 4$ part comes from animal and from that $1 / 4$ part $2 / 3$ parts of the fish are then categorized into two, namely Good and Poor (WNPG, 2012). The analysis used in this research is univariate and bivariate analysis (chi square).

\section{Results}

In the results of the study, $73.4 \%$ of the children who had good parenting and fish consumption were good, while the children who had poor parenting had poor fish consumption, namely $82.4 \%$. So it can be interpreted that the better the parenting style, the better the fish consumption.

From the bivariate results, the variables of parenting affect fish consumption in school-age children with a value smaller than $\mathrm{P}<0.05$ so that there is a significant relationship that affects fish consumption in children. (table 1.)

\section{Discussion}

Parenting style is the attitude of parents in interacting with their children. Attitudes taken by parents include educating, guiding, and teaching values in accordance with the norms practiced in society (Suwono, 2008). Therefore, parenting greatly affects the development of children. Based on the results of the research analysis, it is known that the parenting style of the children is very good, where out of 173 children, there are 108 children with good parenting. Likewise, the consumption of fish in children is very good, where there are 139 children who consume fish properly from a total of 173 children. There is a relationship between parenting and fish consumption in school age children, where the results of the chi square test get a $\mathrm{P}$ value $<0.005$ and an $\mathrm{OR}$ value $=12.86(95 \% \mathrm{CI}$ $4,933-33,552)$ so that good parenting has a 12 times chance that school children consume fish well.

The growth and development of primary school age children will be maximized if the nutritional needs of children can be met. In addition, the habit of healthy eating in the family must be properly instilled so that children can grow and develop optimally (Damayanti and Didit, 2006).

Nutrition in children changes as children grow physically, mentally, and emotionally. Children who do not have enough nutritional needs, especially energy and protein. If this nutrient deficiency for months to years causes the child to grow short (stunted) and their learning achievement is lower than children who get good nutrition (Roth, 2011).

$\underline{\text { Table 1. Bivariate analysis of the relationship between parenting style and fish consumption }}$

\begin{tabular}{|c|c|c|c|c|c|c|}
\hline \multirow[b]{2}{*}{ Variable } & \multicolumn{2}{|c|}{ Fish Consumption } & \multirow[b]{2}{*}{$\begin{array}{c}\text { Total } \\
(n=173)\end{array}$} & \multirow[b]{2}{*}{$\mathbf{P}$} & \multirow[b]{2}{*}{ OR } & \multirow[b]{2}{*}{$95 \% \mathrm{CI}$} \\
\hline & $\begin{array}{c}\text { good } \\
(\mathrm{n}=139)\end{array}$ & $\begin{array}{l}\text { poor } \\
(n=34)\end{array}$ & & & & \\
\hline \multicolumn{7}{|l|}{ Pola Asuh } \\
\hline good & $102(73.4)$ & 37 (26.6) & $108(100)$ & $0,000 *$ & 12.86 & $4.933-33.552$ \\
\hline poor & $6(17.6)$ & $28(82.4)$ & $65(100)$ & & & \\
\hline
\end{tabular}

*Pvalue $<0,05$ 


\section{References}

Alaimo, K., Olson, CM., and Frongillo, EA. (2001). Food Insufficiency and American School-Aged Children's Cognitive, Academic, and Psychosocial Development. Pediatrics; 108.

A. Roth, R. (2011). Nutrition and Diet Therapy 10th Edition. Fort Wayne: Indiana Delmar Cencage.

Bakhtiar, B., Rohaya, S., \& Ayunda, H. M. A. (2019). Penambahan Tepung Tulang Ikan Bandeng (Chanos chanos) Sebagai Sumber Kalsium dan Fosfor Pembuatan Donat Panggang. Jurnal Teknologi dan industri pertanian Indonesia, 11(1), 38-45.

Damayanti, Didit Muhilal. (2006). Gizi Seimbang Untuk Anak Usia Sekolah Dasar. Jakarta: EGC.

Depkes, (2009). Sistem Kesehatan Nasional. Jakarta

Direktorat Jenderal Perikanan Tangkap DKP, 2006. Kebijakan Pengelolaan Sumberdaya Ikan Dalam Rangka Pengelolaan Perikanan Yang Bertanggung Jawab Sebagai Upaya Penanggulangan Konflik Nelayan.

Hardiansyah \& Rimbawan. (2000). Analisis Bahaya dan Pencegahan Keracunan Pangan. Jakarta: Direktorat Jenderal Pendidikan Tinggi Departemen Pendidikan Nasional.

Jas \& Meta. (2004). Hubungan antara pola asuh dengan perkembangan bahasa pada anak usia 13 tahun di Desa Sukolilo Pati. Kudus.
Karsin, ES. (2004). Klasifikasi Pangan dan Gizi, Dalam Pengantar Pangan Dan Gizi. Penebar Swadaya, Jakarta.

Mutiah Wiwiet. (2012). Konsumsi Ikan, Status Gizi Dan Prestasi Belajar Siswa Sekolah Dasar Kelas IV Di Daerah Pantai Dan Daerah Non Pantai. Departemen Gizi Masyarakat Fakultas Ekologi Manusia Institut Pertanian Bogor.

Nurul Salasa Nilawati, S.A. Nugraheni, Freida NRH. (2006). Hubungan Konsumsi ikan Dengan Perkembangan Kognisi Anak Baduta (12-23 Bulan), Studi di Kecamatan Gandus Kota Palembang Tahun 2006. Jurnal Psikologi Fakultas Psikologi Universitas Gadjah Mada Volume 33, No. 2, 1 - 12 ISSN: 0215-8884.

Sujai, Akhmad, Adiyanti Maria Goretti, Emy Huriyati. (2013). Ketahanan pangan rumah tangga, status gizi, dan prestasi belajar siswa sekolah dasar. Vol 9, No 3 (2013). https://jurnal.ugm.ac.id/jgki/article/view/15442

Suwono. (2008). Kemampuan Sosialisasi Anak Prasekolah. from: http // www.Pustaka. ut.ac.id /pustaka.

Suyanto. (2005). Konsep Dasar Anak Usia Dini: Jakarta: Departemen. Pendidikan Nasional

Widyakarya Nasional Pangan dan Gizi VIII. (2004). Ketahanan Pangan Dan Gizi Di Era Otonomi Daerah Dan Globalisasi. Jakarta 